\title{
REALISASI PROGRAM JIMPITAN KARANG TARUNA BUGIS GENERATION DALAM MENINGKATKAN PERAN SOSIAL KEMASYARAKATAN
}

\author{
Fery Diantoro \\ Institut Agama Islam Negeri (IAIN) Ponorogo \\ Email: ferydian11@gmail.com
}

\begin{abstract}
ABSTRAK
Program pengabdian masyarakat ini bertujuan untuk pemberdayaan dengan memberikan fasilitasi kepada karang tarunana BG Generations Dusun Bugis Desa Bekare yang telah memiliki program lama yang belum terealisisi yaitu program jimpitan. Pengabdian dengan metode ABCD dapat meyakinkan kembali bahwa BG Generaitons dapat merealisasikan program jimpitan dan dapat menggugah semangat masyarakat untuk. mendukung kegiatan tersebut. Kegiatan dalam pengebdian ini didasarkan pada metode penemuan apresiatif (appreciative inquiry) yang terdiri dari discovery, dream, design, dan destiny. Inti dari pengabdian ini adalah mendesain untuk merealisasikan program jimpitan, maka dilakukanlah kegiatan sosialisasiyang memberikan pengetahuan kepada masyarakat terkait pentingnya program jimpitan dan memberikan pendampingan atau fasilitasi dengan berpartisipasi dalam penyusunan pengelola, pengumpulan dan pemasangan kaleng sebagai sarana pengumpulan dana jimpitan dan mendampingi menyiapkan pembukuan. Respon masyarakat sangat positif terhadap program jimpitan.
\end{abstract}

Kata kunci: Karang Taruna, Program Jimpitan, Peran Sosial Kemasyarakatan

\begin{abstract}
This community service program aims to empower by providing facilitation to the BG Generations, which has an old program that has not been realized, namely the jimpitan program. The service with the $A B C D$ method can reassure that BG Generaitons can realize the jimpitan program and can inspire the community to support these activities. This devotion activity is based on the appreciative inquiry method which consists of discovery, dream, design, and destiny. The essence of this service is to design to realize the jimpitan program, then socialization activities are carried out that provide knowledge to the community regarding the importance of the jimpitan program and provide assistance or facilitation by participating in the arrangement of managers,
\end{abstract}


collecting and installing cans as a means of collecting funds and assisting in preparing bookkeeping. The community response was very positive to the jimpitan program.

Keywords: Karang Taruna, Jimpitan Program, Social Community Role

\section{PENDAHULUAN}

Dalam pengembangan masyarakat desa, banyak hal yang masih belum disadari masyarakat itu sendiri bahwa keberadaanya memiliki banyak potensi dan aset yang tersimpan. Ketika ada program pemberdayaan atau pengabdian masyarakat, informasi yang diberikan oleh masyarakat banyak aduan-aduan masyarakat tentang kelemahan atau kekurangan dan permasalahan yang dimiliki dan sedikit sekali yang menunjukkan kekuatan atau potensi yang dimiliki. Maka muncullah metode ABCD dalam pengabdian masyarakat untuk paradigma tersebut dan dibalik bahwa sekecilapaun setiap komunitas atau masyarakat pasti punya potensi yang berupa aset, setidak-tidaknya bahwa aset tersebut berupa mimpimimpi atau harapan-harapan untuk maju dan berkembang.

Dusun Bugis merupakan satu dari tiga dusun yang ada di Desa Bekare Kecamatan Bungkal yang memiliki populasi sebanyak 220 jiwa dengan rincian laki-laki (103) dan perempuan (117) yang terbagi dalam $120 \mathrm{KK}$. Potensi SDM yang dimiliki sangat beragam mulai dari petani, pedagang, wirausaha, pengrajin, guru, PNS dan ada juga yang menjadi TKI dan TKW diluar negeri. Dari segi sosial kemasyarakatan, kehidupan di dusun Bugis berjalan damai, tentram tanpa menunjukkan adanya kesenjangan. Kondisi masyarakat juga relatif kondusif karena masyarakatnya masih menjunjung tinggi nilai solidaritas dan masyarakatnya antara satu dengan yang lain masih memiliki ikatan saudara sehingga komunikasi bisa terjalin dengan baik (hasil wawancara dengan Kepala Dusun).

Masyarakat dusun Bugis merupakan model masyarakat yang partisipatif, mereka membuka diri dan memberi respon positif kepada hal yang baru yang dirasa dapat memberi dampak kebaikan dan perkembangan. Dari hasil penelusuran wilayah dengan menggunakan metode ABCD seperti penemuan apresiatif (appreciative inquiry), pemetaan komunitas (community mapping), penelusuran wilayah (transect), pemetaan asosiasi dan institusi, pemetaan aset individu (individual inventory skill). ${ }^{1}$ Ditemukan satu potensi yang dimiliki oleh dusun Bugis yaitu keberadaan karang tarunan yang diberi nama BG Generations. Secara lebih dalam ditemukan bahwa BG Generations memiliki rencana yang belum terealisasi yang berupa program jimpitan.

Hal positif dari keberadaan karangtaruna yang terdiri dari generasi muda adalah sebagai generasi yang kelak akan meneruskan tongkat estafet kepemimpinan dimasa yang akan datang, sehingga dibutuhkan generasi yang terampil, berakhlak, bermoral serta cinta tanah air dan dapat diandalkan di tengah masyarakat terutama bangsa dan negara.

\footnotetext{
Buku Pedoman KPM ABCD (LPPM IAIN Ponorogo, 2019), 55.
} 
Program jimpitan secara umum merupakan sebuah program sosial swadaya masyarakat. Secara normatif program jimpitan bila dijalankan dengan baik merupakan potensi besar untuk membangun sebuah komunitas atau masyarakat. Hasil dari jimpitan dapat dimanfaatkan untuk membantu sesama yang membutuhkan, untuk memenuhi kebutuhan umum dan masih banyak manfaat lainnya.

Artikel ini disusun dari hasil pengabdian kepada masyarakat yang dikemas dalam bentuk kuliah pengabdian masyarakat yang dilakukan oleh kelompok 02 dari IAIN Ponorogo. Kolaborasi antara dosen pembimbing dengan peserta dalam melaksanakan pengabdian memilih tema tentang pemberdayaan karang tarunan. Pilihan tema ini ditentukan melalui metode ABCD. Fokus dari pengabdian ini terletak pada pengaktifan kegiatan jimpitan dan pemberdayaan karang taruna BG Generations Dusun Bugis Desa Bekare dalam mengelola jimpitan. Tujuan dari pengabdian ini diarahkan pada pengembangan kegiatan dan pemberdayaan karang taruna dalam membangun solidaritas dan rasa kepedulian antar sesama di masyarakat.

\section{METODE}

Pedekatan yang dilakukan dalam pengabdian ini adalah pendekatan Asset Based Community-driven Development atau yang lebih dikenal dengan pendekatan ABCD. Pendekatan ini lebih fokus terhadap kekuatan dan kemampuan yang dimiliki oleh komunitas meskipun hal itu sangatlah kecil walau hanya sebatas mimpi. Prinsip yang dikembangkan pendekatan ini adalah 1). Setengah terisi lebih berarti (half full and half empty), 2). Semua punya potensi (no body has nothing), 3). Partisipasi (participation), 4). Kemitraan (partnership), 5). Penyimpangan positif (positive deviance), 6). Berasal dari dalam masyarakat (endogenous), dan 7). Mengarah pada sumber energi (beliotropic). ${ }^{2}$ Selain prinsip, ABCD juga mengembangkan tujuh metode dan alat menemukenali dan mobilisasi aset yaitu: 1) Penemuan Apresiatif (Appreciative Inquiry), 2) Pemetaan Komunitas (Community Mapping), 3) Penelusuran Wilayah (Transect), 4) Pemetaan Asosiasi dan Institusi, 5) Pemetaan Aset Individu (Individual Inventory Skill), 6) Sirkulasi Keuangan (Leaky Bucket), dan 7) Skala Prioritas (Low Hanging Fruit).

\section{ANALISIS DAN PEMBAHASAN}

Pembahasan ini menggunakan pendekatan dari salah satu metode dan alat menemukenali dan mobilisasi aset yaitu Appreciative Inquiry atau penemuan apresiatif. Alat ini dipilih dalam upaya mendalam untuk memastikan program jimpitan dapat terlaksana. Langkah ini merupakan sebuah langkah baru untuk mengembangkan sebuah komunitas dengan memberikan penegasan dan penguatan terhadap nilai, kekuatan maupun potensi yang dimi-

\footnotetext{
2 Buku Pedoman KPM ABCD, 29.
} 
liki. ${ }^{3}$ Appreciative Inquiry merupakan cara yang positif dalam melakukan perubahan pada komunitas berdasarkan asumsi sederhana yaitu bahwa setiap komunitas memiliki sesuatu yang dapat bekerja dengan baik, sesuatu yang menjadikan organisasi hidup, efektif dan berhasil, serta menghubungkan organisasi tersebut dengan komunitas dan stakeholdernya dengan cara yang sehat. Proses Appreciative Inquiry terdiri dari 4 tahap yaitu: Discovery; Dream; Design; dan Destiny.

Tahap pertama Discovery yaitu proses pencarian yang mendalam tentang hal-hal positif, hal-hal terbaik yang pernah dicapai, dan pengalaman-pengalaman keberhasilan di masa lalu. Proses ini dilakukan dengan melaksanakan wawancara appresiatif terhadap masyarakat dusun Bugis Desa Bekare, terkait hal yang pernah dilakukan dan menjadi kebanggaan. Ditemukan bahwa di dusun Bugis memiliki tingkat kerukuanan yang sangat baik dengan mata pencaharian sebagian besar sebagai wirausaha. Wujud soliditas dan kekome pakan ditunjukkan dengan adanya organisasi karang tarunan yang bernama BG Generation dan salah satu impian dari komunitas pemuda ini yang belum terwujud adalah pengadaan program jimpitan.

Dipilihnya karang taruna BG Generation dengan program jimpitan sebagai fokus pengabdian, dasarnya bahwa karang taurana BG Generation merupakan satu komunitas pemuda dan pemudi (sinoman) yang aktif di dusun Bugis. Banyak hal yang telah dilakukan diantaranya mewujudkan lampu penerangan jalan dan membantu membangun rumah salah satu warga yang kurang mampu. Pemilihan program jimpitan dikarenakan program yang pernah direncanakan namun belum terlaksana karena terhambat oleh faktor kepercayaan dan teknis lainnya.

Mengutip dari wikipedia, ${ }^{4}$ Karang Taruna adalah organisasi kepemudaan di Indonesia. Karang Taruna merupakan wadah pengembangan generasi muda non partisan, yang tumbuh atas dasar kesadaran dan rasa tanggung jawab sosial dari, oleh dan untuk masyarakat khususnya generasi muda di wilayah Desa/ Kelurahan atau komunitas sosial sederajat, yang terutama bergerak di bidang kesejahteraan sosial.

Sebagai organisasi sosial kepemudaan Karang Taruna merupakan wadah pembinaan dan pengembangan serta pemberdayaan dalam upaya mengembangkan kegiatan ekonomi produktif dengan pendayagunaan semua potensi yang tersedia di lingkungan baik sumber daya manusia maupun sumber daya alam yang telah ada. Sebagai organisasi kepemudaan, Karang Taruna berpedoman pada Pedoman Dasar dan Pedoman Rumah Tangga di mana telah pula diatur tentang struktur pengurus dan masa jabatan di masing-masing wilayah

3 Jaeni Dahlan, "Pemanfaatan Aset Komunitas Melalui Pendekatan Appreciative Inquiry Dalam Penanggulangan Kemiskinan Di Kabupaten Bandung Barat," Pekerjaan Sosial 15, no. 2 (2016), https://doi.org/10.31595/peksos.v15i2.87.

4 Wikipedia, "Karang Taruna," n.d., https://id.wikipedia.org/wiki/Karang_Taruna. diakses tanggal 25 September 2019 
mulai dari Desa/ Kelurahan sampai pada tingkat Nasional. Semua ini wujud dari pada regenerasi organisasi demi kelanjutan organisasi serta pembinaan anggota Karang Taruna baik di masa sekarang maupun masa yang akan datang. ${ }^{5}$

Keberadaan karang tarunana BG Generations yang berada di dusun Bugis Desa Bekare sangatlah tepat, karena keberadaannya dapat memberikan kontribusi yang signifikan terhadap peningkatan peran sosial kemasyarakatan. BG Generation dapat melakukan banyak aktivitas kemasyarakatan. Setiap karang taruna mempunyai tugas pokok secara bersama-sama dengan pemerintah dan komponen masyarakat lainya untuk menanggulangi berbagaimana kesejahteraan sosial terutama yang di hadapi generasi muda, baik yang bersifat preventif, rehabilitatif maupun pengembangan potensi generasi muda di lingkungannya. ${ }^{6}$

Jimpitan adalah kegiatan pengumpulan sesuatu (berupa uang atau beras) yang di lakukan dari rumah ke rumah, dengan jumlah yang sedikit (beras: satu genggam, uang: Rp. 500,-) secara kontinyu, sesuai keikhlasan/kerelaan pemberi. Biasaya dana dari jimpitan digunakan untuk kegiatan sosial di suatu komunitas wilayah (RT/RW). Sejalan dengan pendapat Surono jimpitan adalah kegiatan pada masyarakat Jawa yang berupa pengumpulan beras atau uang yang dilakukan oleh anggota masyarakatnya dari satu rumah ke rumah lainnya pada malam hari ${ }^{7}$. Secara fisik kegiatan ini apabila dijalankan dengan benar akan memberi manfaat yang sangat besar bagi pembangunan desa pada umumnya dan lingkup RT/RW pada khususnya.

Program jimpitan selain menghasilkan hal yang berbentuk finansial, juga dapat menanamkan nilai keteraturan dan keselarasan dalam masyarakat yang menjadi suatu hal yang penting dalam sosial kemasyarakatan. ${ }^{8}$ Dalam pandangan Jawa prinsip-prinsip keselarasan harus didahulukan terhadap hukum positif. Nilai-nilai inilah yang tercermin dalam program jimpitan, dengan masyarakat secara bersama-sama berpartisipasi dalam bergotong royong dan bahu membahu mewujudkan program jimpitan.

Tahapan yang kedua adalah Dream. Kegiatan ini adalah mengeksplorasi harapan dan impian mereka baik untuk diri mereka sendiri maupun untuk organisasi. Inilah saatnya orang-orang memikirkan hal-hal besar dan berpikir out of the box serta membayangkan hasil-

\footnotetext{
5 Yoga Finoza Crisandye, "Peran Karang Taruna Dalam Pengembangan Kreativitas Remaja (Studi Kasus Di Karang Taruna Remaja Kita RW 14 Kelurahan Cibeber Kecamatan Cimahi Selatan)," Comm-Edu (Community Education Journal) 1, no. 3 (September 29, 2018): 94-100, https://doi.org/10.22460/comm-edu.v1i3.2101.

6 Ronny Setiawan, "Peran Karang Taruna dalam Meningkatkan Aktivitas Kepemudaan di Kelurahan Gunung Lingai Kecamatan Sungai Pinang Kota Samarinda" 7 (n.d.): 14.

7 Surono, "Build The Economic Integration With Jimpitan Model In Javanese Society" (2nd International Conference on International Relations and Development (ICIRD 2012) 'Towards an ASEAN EconomicCommunity (AEC) - Prospects, Challenges, and Paradoxes in Development,Governance and Human Security, Chiang Mai, Thailand, 2012).

8 Suwardi Endraswara, Etika Hidup Orang Jawa (Yogyakarta: Penerbit Narasi, 2010), 15.
} 
hasil yang ingin dicapai. Tahapan ini menindaklanjuti dari tahapan pertama terutama impian karang tarunan BG Generation untuk mewujudkan program jimpitan yang telah menjadi rencana dimasa lalu namum belum segera terwujud disebabkan beberapa kendala. Pada point ini yang dilakukan adalah kembali menggugah gairah dan memotivasi dengan mengidupkan kembali impian terkait program jimpitan, yang mana hal tersebut akan memberikan dampak yang sangat luar biasa terhadap peran sosial kemasyarakatan.

Tahapan ketiga yaitu Design. Pada tahap design ini, orang mulai merumuskan strategi, proses dan sistem, membuat keputusan dan mengembangkan kolaborasi yang mendukung terwujudnya perubahan yang diharapkan. Proses dalam tahap ini adalah mengajak komunitas karang tarunan untuk kembali membangun kerjasama pada komunitas untuk mendesain atau menyusun rencana pelaksanaan program jimpitan. Hal yang dapat dilakukan adalah dengan menganalisis pengalaman kegagalan dalam realiasasi untuk diambil sisi positifnya yang dapat ditransformasikan menjadi kekuatan untuk mewujudkan program jimpitan.

Pada tahapan ini banyak hal yang dilakukan untuk membuat program dapat dilaksakan dengan baik, diantaranya yaitu dilakukannya sosialisasi program kepada masayarakat, pendampingan kepada karang taruna BG Generation dalam menyusun pengelola yang bertanggung jawab mengurusi jimpitan dan pendampingan pembukuan atau pencatatan jimpitan.

Sosialisasi dilakukan sebagai bentuk pendidikan terhadap masyarakat terkait program yang akan dilaksanakan. Sosialisasi adalah proses penanaman atau transfer kebiasaan atau nilai dan aturan dari satu generasi ke generasi lainnya dalam sebuah kelompok atau masyarakat. Tujuan sosialisasi adalah memberikan keterampilan kepada seseorang untuk dapat hidup bermasyarakat dan mengembangkan kemampuan seseorang dalam berkomunikasi secara efektif, mengembangkan fungsi-fungsi organik seseorang melalui introspeksi yang tepat, menanamkan nilai-nilai dan kepercayaan kepada seseorang yang mempunyai tugas pokok dalam masyarakat.

Secara teknis kegiatan sosialisasi diawali dengan koordinasi dan konsultasi bersama ketua karang taruna, kepala dusun dan kepala desa. Bersama dengan pengurus karang taruna sosialisai program jimpitan dilaksanakan kepada jama'ah yasinan bapak-bapak. Kegiatan jimpitan tersebut akan dikelola oleh karang taruna dengan membentuk pengurus jimpitan mulai dari ketua, sekretaris, bendahara, dan juga petugas pengambilan uang di omplong/ kaleng jimpitan di setiap akhir bulannya. Respon positif dari peserta dengan memberikan tanggapan bahwa dengan adanya jimpitan bisa melatih masyarakat untuk menjadi orang yang ikhlas dalam beramal, dan sebagian besar jama'ah juga setuju dengan apa yang disosialisasikan. Dari hasil sosialisasi didapat persetujuan, bahwa untuk pelaksanaan program jimpitan dapat dilaksanakan di masyarakat Dusun Bugis.

Bahwa jimpitan itu merupakan realisasi sikap sosial masyarakat yang dituangkan dalam bentuk pemberian sesuatu berupa uang di kaleng jimpitan yang disediakan oleh 
panitia pengelola jimpitan, dengan tujuan untuk kegiatan sosial kemasyarakatan. Satu langkah yang tepat bagi masyarakat Dusun Bugis untuk melaksanakan program jimpitan karena akan semakin meningkatkan soliditas, solidaritas dan kebersamaan. Peran sosial kemasyarakatan juga akan terjaga dengan baik. Harapan besar kami dengan adanya program jimpitan, akan memberikan kontribusi kepada masyarakat Dusun Bugis. Melalui dana yang terkumpul dari jimpitan dapat digunakan untuk kegiatan sosial maupun kegiatan dari karang taruna Dusun Bugis. Selain itu kiranya program jimpitan ini dapat digunakan oleh karang taruna sebagai jalan untuk mempererat kekeluargaan antara karang taruna dan juga masyarakat Dusun Bugis.

Pendampingan kepada karang taruna BG Generation dalam menyusun pengelola jimpitan, bahwa pengelola jimpitan disusun semi otonom dari organisasi karang taruna BG Generation. Dari kepengurusan panitia jimpitan keseluruhannya diambilkan dari karang taruna putri, dengan tujuan untuk mempererat komunikasi dengan masyarakat sekitar dan agar karang taruna putri lebih aktif dalam kegiatan karang taruna melalui kegiatan jimpitan ini. Selanjutnya dari kepengurusan yang sudah dibuat dan disetujui oleh seluruh anggota Karang Taruna selanjutnya kepengurusan ini akan diforumkan kepada masyarakat Dusun Bugis pada saat kegiatan rutin masyarakat.

Untuk memastikan pengelolaan jimpitan berjalan dengan baik, pendampingan juga dilakukan terhadap bendahara yaitu tentang pembukuan. Kegiatan pencatatan hasil jimpitan adalah hal yang sangat urgen untuk menjaga kepercayaan masyarakat. Sehingga dibutuhkan pencatatan yang rapi dan dapat dipertanggungjawabkan. Pendampingan ini berbentuk belajar bersama dalam menyusun laporan hasil jimpitan yang dikumpulkan oleh petugas pengambil jimpitan dari rumah-rumah pada buku kas dan buku transaksi keluar dan masuknya uang hasil jimpitan.

Tahapan terakhir adalah Destiny atau tahap di mana setiap orang dalam organisasi mengimplementasikan berbagai hal yang sudah dirumuskan pada tahap design. Destiny menjadi bukti dari apa yang diimpikan dan yang telah didesain untuk menjadi program yang nyata. Dari hasil pengamatan pasca pengabdian bahwa program jimpitan yang digerakkan oleh karang taruna BG Generation Dapat berjalan dengan baik. Antusiasme masyarakat yang tinggi dalam menigisi kaleng jimpitan.

\section{KESIMPULAN}

Berdasarkan dari beberapa penjabaran di atas, pengabdi merasakan bahwa kegiatan yang telah disusun selama ini, serta telah dilaksanakan memberi dampak positif bagi masyarakat di dusun Bugis Desa Bekare. Adapun kegiatan ini dapat dilaksanakan secara berkala dan dievaluasi untuk mengetahui kelanjutan dari program ini yang dijalankan oleh pengelola.

Karang taruna yang sebagian besar anggotanya adalah pemuda dan pemudi (sinoman) 
memiliki potensi besar untuk membangun komunitas atau masyarakat. Sehingga keaktifannya dalam kegiatan kemasyarakatan sangat dibutuhkan. Terbukti apa yang telah dilakukan oleh karang tarunan BG Generation Dusun Bugis Desa Bekare, yang dapat menghadirkan program jimpitan dan program-program lainnya. Jimpitan adalah program gotong royong dengan memberikan sumbangan yang diwadahi dalam kaleng yang dipasang di setiap rumah dan pengumpulannya secara periodik. Kegiatan ini sangat dibutuhkan karena hasil jimpitan dapat digunakan untuk keperluan masyarakat.

Program jimpitan yang dilaksanakan oleh karang taruna BG Generation secara umum mendapatkan tanggapan dari masyarakat dengan merespon baik dan juga masyarakat ikut melaksanakan program tersebut. Hal ini terbukti ketika kaleng jimpitan sudah dipasang warga juga antusias dalam mengisi kaleng tersebut.

Rekomendasi yang dapat kami berikan adalah besar harapan disampaikan kepada pemerintah desa dapat memberikan dukungan secara formal terhadap program jimpitan dan dapat memberlakukan di seluruh wilayah desa. Selain itu harapan kami proses monitoring senantiasa diberikan kepada pengelola program jimpitan.

\section{DAFTAR PUSTAKA}

Tim LPPM IAIN Ponorogo. (2019). Muku Pedoman KPM ABCD. LPPM IAIN Ponorogo.

Crisandye, Yoga Finoza. "Peran Karang Taruna dalam Pengembangan Kreativitas Remaja

(Studi Kasus Di Karang Taruna Remaja Kita RW 14 Kelurahan Cibeber Kecamatan

Cimahi Selatan).” Comm-Edu (Community Education Journal) 1, no. 3 (September 29, 2018): 94-100. https://doi.org/10.22460/comm-edu.v1i3.2101.

Dahlan, Jaeni. "Pemanfaatan Aset Komunitas melalui Pendekatan Appreciative Inquiry

dalam Penanggulangan Kemiskinan di Kabupaten Bandung Barat.” Pekerjaan Sosial 15, no. 2 (2016). https:/ / doi.org/10.31595/peksos.v15i2.87.

Endraswara, Suwardi. (2010). Etika Hidup Orang Jawa. Yogyakarta: Penerbit Narasi.

Setiawan, Ronny. "Peran Karang Taruna dalam Meningkatkan Aktivitas Kepemudaan di Kelurahan Gunung Lingai Kecamatan Sungai Pinang Kota Samarinda” 7 (n.d.): 14.

Surono. (2012). "Build The Economic Integration With Jimpitan Model In Javanese Society." Chiang Mai, Thailand.

Wikipedia. "Karang Taruna,” n.d. https://id.wikipedia.org/wiki/Karang_Taruna. 